\title{
THE SOUTH WEST AFRICA CASES: UT RES MAGIS PEREAT QUAM VALEAT
}

In Article 119 of the Treaty of Peace, signed at Versailles in 1919, Germany renounced all rights in her overseas possessions in favor of the Principal Allied and Associated Powers; among these possessions was German South West Africa. In 1920, this territory was entrusted to the Union of South Africa under a mandate conferred upon the King of England, pursuant to Article 22 of the Covenant of the League of Nations. ${ }^{1}$ The Mandates System established in Article 22 of the Covenant was a novel alternative to the historical practice of annexation of the territories of nations defeated in war. It was only after heated debate and the vigorous advocacy of President Woodrow Wilson that the Allied Powers embraced the principles of the system. ${ }^{2}$

The Mandates System was based on the ideal that advanced nations should undertake to carry out a "sacred trust of civilization" to promote the "well-being and development" of "peoples not yet able to stand by themselves under the strenuous conditions of the modern world." 3 The essential terms of the "sacred trust" were broadly stated in Article 2, pargaraph 2, of the Mandate for German South West Africa: "The Mandatory shall promote to the utmost the material and moral well-being and the social progress of the inhabitants of the territory subject to the present Mandate."

Following the dissolution of the League of Nations after the Second World War, it became the stated intention of the South African government to incorporate the mandated territory into the Union. This, however, was unacceptable to the General Assembly of the United Nations. ${ }^{4}$ Subsequently, when the Trusteeship System ${ }^{5}$ was instituted, the Union of South Africa was the only mandatory which refused to yield its dominion over a mandated territory. Because of the demise of the organization which had created the Mandates System and the refusal of the Union to place South West Africa

1 It is noteworthy that South West Africa was one of the territories:

which, owing to the sparseness of their population, or their small size, or their remoteness from the centres of civilization, or their geographical continuity to the territory of the Mandatory, and other circumstances can be best administered under the laws of the Mandatory as integral portions of its territory, subject to the safeguards above mentioned in the interests of the indigenous population.

League of NATIONS Covenant art. 22, para. 6. (Emphasis added.) Among the "laws" of the Union of South Africa are those which establish and enforce the policy known as apartheid, the segregation of the races.

2 South West Africa Cases, [1966] I.C.J. 217 (second phase).

3 League of Nations Covenant art. 22, para. 1.

4 International Status of South West Africa, [1950] I.C.J. 142-43 (advisory opinion).

5 The trusteeship system was established by the U.N. CenARTER ch. XII; it applied to territories still under Mandate at the end of World War II. 
under the Trusteeship System, the General Assembly adopted a resolution seeking an advisory opinion from the International Court of Justice on the status of the Territory. ${ }^{6}$

In 1950, the Court ruled that the Mandate had survived the dissolution of the League and that, consequently, two obligations under the Mandate remained in force: 1) to "promote to the utmost the material and moral well-being and the social progress of the inhabitants"; 2) to submit annual reports on the administration of the Territory and to transmit petitions from the indigenous peoples to the United Nations General Assembly, in lieu of the League Council. ${ }^{7}$ Significantly, the Court also ruled that, by virtue of Article 37 of the Statute of the International Court of Justice ${ }^{8}$ and Article 80(1) of the Charter of the United Nations, ${ }^{9}$ Article 7 of the Mandate ${ }^{10}$ was still in force; therefore, the Union of South Africa would be obliged to accept the compulsory jurisdiction of the Court as successor to the Permanent Court of International Justice. ${ }^{11}$

The cases which are the subject matter of this Comment were brought before the International Court of Justice on November 4, 1960, by the governments of Ethiopia and Liberia, two former members of the League of Nations. ${ }^{12}$ The substance of their claims was that, inter

(International Status of South West Africa, [1950] I.C.J. 129 (advisory opinion.)

7 Id. at $133,136$.

8 I.C.J. Stat. art. 37, provides:

Whenever a treaty or convention in force provides for references of a matter to a tribunal to have been instituted by the League of Nations, or to the Permanent Court of International Justice, the matter shall, as between the parties to the present Statute, be referred to the International Court of Justice. 9 U.N. CenARTER art. 80 , para. 1, provides:

Except as may be agreed upon in individual trusteeship agreements under Articles 77, 79, and 81, placing each territory under the trusteeship system, and until such agreements have been concluded, nothing in this Chapter shall be construed in or of itself to alter in any manner the rights whatsoever of any states or any peoples or the terms of existing international instruments to which Members of the United Nations may respectively be parties.

10 Mandate for German South West Africa, art. 7, para. 2, 2 League of Nations OFF. J. 89 (1921), provides:

The Mandatory agrees that, if any dispute whatever should arise between the Mandatory and another Member of the League of Nations relating to the interpretation or the application of the provisions of the Mandate, such dispute, if it cannot be settled by negotiation, shall be submitted to the Permanent Court of International Justice provided for by Article 14 of the Covenant of the League of Nations.

11 International Status of South West Africa, [1950] I.C.J. 138 (advisory opinion). The Court also held that there was no obligation to place the territory under a trusteeship. Id. at 144 .

12 Although Ethiopia and Liberia filed separate applications, they were treated as a single party for the purpose of choosing a judge ad hoc and may be regarded as a single party for the purpose of the litigation. South West Africa Cases, [1962] I.C.J. 321 (preliminary objections). If the bench does not include a judge of the nationality of one or both of the parties to a case, such party or parties may choose an ad hoc judge to sit on the case. I.C.J. Stat. ch. 1.

For the background of the litigation, see generally The South West Africa Cases: A Symposinm, 4 CoLUM. J. INT'L L. 47 (1965) and authorities cited therein. For a political science viewpoint of the litigation, see D'Amato, Legal and Political Strategies of the South West Africa Litigation, 4 L. IN TRANSITION Q. 8 (1967). 
alia, the pursuit of apartheid was violative of the obligations which the Union of South Africa had undertaken as Mandatory of South West Africa. On November 3, 1961, the government of the Union filed four preliminary objections. ${ }^{13}$

In rejecting the preliminary objections of the Union, the Court held the following: 1) that the Mandate, notwithstanding the dissolution of the League, was a "treaty or convention in force" within the meaning of Article 37 of the Statute of the Court, and that the validity of Article 7 of the Mandate was not affected by the dissolution; 2) that the governments of Ethiopia and Liberia qualified as "another Member of the League of Nations" within the meaning of Article 7, despite the fact that the League had ceased to exist; 3 ) that there was a "dispute" within the meaning of Article 7 despite the fact that the material interests of the applicants were not involved; 4) that the dispute before the Court was one which "cannot be settled by negotiation" within the meaning of Article 7. On the basis of these conclusions the Court found that it had "jurisdiction to adjudicate upon the merits of the dispute." 14

Although the Court in 1962, in rejecting the preliminary objections, had decided that it had jurisdiction to adjudicate the merits of the case even though only non-material interests were involved, the Court in 1966, in the second phase of the case, held that the applicants' claims were inadmissible because the Mandate was never intended to confer substantive rights on members of the League of Nations where the material interests of the States were not involved. ${ }^{15}$

\section{THE 1966 DeCISION}

The Court in 1966 framed the question of admissibility thus: [T] here was one matter that appertained to the merits of the case but which had an antecedent character, namely the question of the Applicants' standing in the present phase of the proceedings-not, that is to say, of their standing before the Court itself, which was the subject of the Court's decision in 1962, but the question, as a matter of the merits of the case, of their legal right or interest regarding the subjectmatter of their claim, as set out in their final submissions. ${ }^{16}$

The Court then distinguished between two kinds of provisions contained in the mandates: the "conduct" provisions and the "special interests" provisions. The former, according to the Court, related to the carrying out of the mandates as mandates. These were "articles defining the Mandatory's powers, and obligations in respect of the

13 South West Africa Cases, [1962] I.C.J. 326-27 (preliminary objections).

$14 I d$. at 347.

15 South West Africa Cases, [1966] I.C.J. 6 (second phase).

$16 I d$. at 18 . 
inhabitants of the territory and towards the League and its organs." 17 These so-called "conduct" provisions were the heart of the "sacred trust." The "special interests" provisions, on the other hand, were those provisions conferring material benefits "directly upon the members of the League as individual States, or in favour of their nationals." 18 In regard to the Mandate for South West Africa, there was but one "special interests" provision, in Article 5, which established the rights of "all missionaries, nationals of any State Member of the League of Nations, to enter into, travel and reside in the territory for the purpose of prosecuting their calling." 19

Having thus defined its terms, the Court then posed the question: whether, according to the scheme of the mandates and of the mandates system as a whole, any legal right or interest .. . was vested in the members of the League of Nations, including the present Applicants, individually and each in its own separate right to call for the carrying out of the mandates as regards their "conduct" clauses;-or whether this function must, rather, be regarded as having appertained exclusively to the League itself, and not to each and every member State, separately and independently. In other words, the question is whether the various mandatories had any direct obligation towards the other members of the League individually, as regards the carrying out of the "conduct" provisions of the mandates. ${ }^{20}$

The Court concluded that, even when the League of Nations still existed, the Applicants did not, in their individual capacity as States, possess any separate right which they could assert, independent of, or in addition to, the right of the League, in pursuit of its collective, institutional activity, to require the due performance of the Mandate in discharge of the "sacred trust." 21

In the Court's view, the function of the League in regard to the "conduct" provisions of the Mandate precluded individual members of the League from claiming substantive rights which would enable them to compel enforcement of the Mandatory's "conduct" obligations. Adverting to the "juridical character and structure" of the League of Nations, the Court found one element of primary importance to be that Article 2 of the Covenant provided that the "action of the League

17 Id. at 20 .

18 Ibid.

19 Mandate for German South West Africa, art. 5, 2 LEAgue of Natrons OFF. J. 89 (1921). Article 5 of the Mandate was also a "conduct" provision in the sense that it created a duty in the Mandatory to "ensure in the territory freedom of conscience and the free exercise of all forms of worship." Ibid.

20 South West Africa Cases, [1966] I.C.J. 22 (second phase). (Emphasis added.)

21 Id. at 29. 
under this Covenant shall be effected through the instrumentality of an Assembly and of a Council, with a permanent Secretariat." ${ }^{22}$ If the relationship between the League and the Mandatory was to be effectuated through the League Council, it followed, arguably, that League members did not have individual rights in the general obligations under the Mandate, absent some provision in the Covenant to that effect. ${ }^{23}$ This institutional set-up, coupled with the fact that under Article 22 of the Covenant the tutelage was to be exercised by the mandatories "on behalf of the League," suggested to the Court that the responsibility for the mandates resided in the League as a whole. Furthermore, in the third paragraph of the preamble of the Mandate for South West Africa, His Britannic Majesty, on behalf of the Union of South Africa, had agreed to accept the Mandate and exercise it "on behalf of the league," not, the Court pointed out, on any other behalf. ${ }^{24}$

The Court further noted that Article 22, paragraph 1 of the Covenant provided that "securities for the performance" of the sacred trust were to be "embodied in the Covenant." ${ }^{25}$ But the Covenant contained no security in the form of a substantive right in the individual Members of the League to enforce the Mandatory's duties to the inhabitants under the Mandate, or a right of recourse to the Court. ${ }^{26}$ Apart from the jurisdictional clause, the individual Members of the League were mentioned only in connection with the "special interests" provisions of the various mandates; these provisions establish the only direct link between the Mandatory and the individual members of the League. ${ }^{27}$

In the "conduct" provisions, moreover, there existed a link between the Mandatory and the League and its organs. In the Court's view, the function of the members of the League in regard to the "sacred trust" was to activate the organs of the League to whom the Mandatory was responsible. The only means of enforcing the sacred trust was through the League Council, to which the Mandatory was required to make annual reports under Article 6 of the Mandate. In addition, Article 7, paragraph 1 required only the consent of the League

22 Id. at 23-24.

$23 \mathrm{Id}$. at 24 .

24 Ibid.

25 There followed an enumeration of the securities for the performance of the sacred trust which were embodied in the Covenant, among which were the duty to furnish annual reports to the satisfaction of the Council of the League and the establishment of a Permanent Mandates Commission. Id. at 25.

26 The Court continually evinced a reluctance to expose the Mandatory to obobligations which it had not expressly and unequivocally assumed. Compare this narrow, contractual approach with that of the Court in its 1950 opinion on International Status of South West Africa, [1950] I.C.J. 128.

27 "[T]he Mandatory . . . shall allow all missionaries, nationals of any State Member of the League of Nations, to enter into, travel and reside in the territory for the purpose of prosecuting their calling." MANDATE FOR GERMan South WeSt Africa, art. 5, 2 League of Nations OFF. J. 89 (1921). 
Council for "any modification of the terms of the . . . Mandate"; 28 the consent of the individual members of the League was not required.

The Court also observed-perhaps to illustrate the voluntary or political nature of the obligations under the Mandate-that the Council could never have imposed its views upon an unwilling mandatory because of the "unanimity rule."

In the Council, which the mandatory was entitled to attend as a member for the purpose of any mandate entrusted to it, if not otherwise a member-(Article 4, paragraph 5, of the Covenant), the vote of the mandatory, if present at the meeting, was necessary for any actual "decision" of the Council, since unanimity of those attending was the basic voting rule on matters of substance in the main League organs-(Article 5, paragraph 1, of the Covenant). Thus there could never be any formal clash between the mandatory and the Council as such. ${ }^{29}$

The Court also pointed to the power of the Council to seek an advisory opinion from the Permanent Court of International Justice, a decision which would not, of course, be binding on the Mandatory. In the context of these procedures, the Court found "out of place" the

existence of substantive rights for individual members of the League in the conduct of the mandates (particularly if backed up by a right of recourse to the Court) exercisable independently of the Council at the will of the member State. ${ }^{30}$

Thus, the Mandate was interpreted as a document of limited enforceability. The existence of rights which might bind the Mandatory against its will was inconsistent with the obligations assumed thereunder, save in regard to the "special interests" provisions. ${ }^{31}$

That the resulting decision rendered the "sacred trust of civilization" unenforceable did not unduly trouble the Court.

28 South West Africa Cases, [1966] I.C.J. 28 (second phase).

29 Id. at 44.

$30 I d$. at 45. It is difficult to see how it follows from the fact that certain obligations of the Mandatory were not enforceable in one manner-through the League Council- that these obligations were also not enforceable before the Court.

31 The plain fact is that, in relation to the "conduct" provisions of the mandates, it was never the intention that the Council should be able to impose its views on the various mandatories-the system adopted was one which deliberately rendered this impossible. It was never intended that the views of the Court should be ascertained in a manner binding on mandatories, or that mandatories should be answerable to individual League members as such in respect to the "conduct" provisions of the mandates.

South West Africa Cases, [1966] I.C.J. 46 (second phase). This language refers to "ascertaining" the "views" of the Court, not to enforcing international obligations or to applying international norms or standards. This suggests a value judgment as to the role of the Court in the uitimate issue on the merits of the case, as well as a limited conception of the scope of the rule of law in the international area. 
In the international field, the existence of obligations that cannot in the last resort be enforced by any legal process, has always been the rule rather than the exception-and this was even more the case in 1920 than today. ${ }^{32}$

Similarly, the Court stated that the risk that a mandatory might administer its mandate contrary to the wishes of the Council, and in contempt of the mandate, was a risk "evidently taken with open eyes." 33 The fact that here the obligations of the Mandatory were made nugatory by the Court's decision was preferable to the applicants' contention, which

would involve acceptance of the proposition that even if the Council of the League should be perfectly satisfied with the way in which a mandatory was carrying out its mandate, any individual member of the League could independently invoke the jurisdiction of the Court in order to have the same conduct declared illegal, although, as mentioned earlier, no provision for recourse to the Court was included amongst the "securities" provided for by the Covenant itself. ${ }^{34}$

The Court here envisioned a parade of horribles: a multiplicity of suits brought by the Members of the League-"some 40 or 50 independent centres of invigilatory rights" ${ }^{35}$-each action badgering the Mandatory with an individual notion of what system might better serve the inhabitants of the Territory. ${ }^{36}$ This fear, coupled with the fact that the League Council might have approved fully of the administration of the mandate under attack, led the Court to conclude that this result was neither what the framers of the mandates had intended nor what this Mandatory had agreed to.

\section{The Preclussive Effect of the 1962 Judgment}

At first blush, it seems that the Court reversed itself in $1966 .^{37}$ There is, however, a difference between the questions decided in 1962

32 Ibid.

33 Ibid.

$34 I d$. at $46-47$.

$35 I d$, at 31 .

36 This vision assumes, however, the lack of a sufficient legal standard which the Court might apply without interfering. with the discretionary power of the Mandatory. With such a standard, the individual views of the member States would not be relevant. Furthermore, the fact that the League Council might be satisfied with the administration is irrelevant as well, if it were the intention of the parties to the Mandate that the Court should apply legal standards to the Mandatory's conduct.

37 The following excerpt from an editorial in the New York Times International Edition serves to illustrate the popular response:

One reason why the decision will provoke enduring argument among lawyers is the remarkable 7-to-7 deadlock of the justices on so important a case. This required the vote of the Court's president, Sir Percy C. Spender of Australia, to produce a verdict, which in effect reversed a previous verdict of the same court on the same case.

N.Y. Times Int'l Ed., July 21, 1966, p. 4, col. 1. 
and in 1966. In order to understand the difference between the scope of the two judgments, the following distinctions should be made.

The jurisdictional question raised by the respondent's third preliminary objection in 1962 may be posed thus: whether the applicant States were those intended to have a right to be before the Court pursuant to the jurisdictional clause (Article $7(2)$ ) in regard to whatever substantive rights might be embodied in the Mandate. Specifically, the question before the Court was whether this right could be defeated because the dispute involved solely the non-material interests of the applicants. The question is perhaps properly termed one of subject-matter jurisdiction, ${ }^{38}$ involving an interpretation of Article 7.

The question before the Court in 1966, involving the admissibility of the claims may be posed thus: whether the parties having standing before the Court to invoke the substantive provisions of the Mandate were vested with a right of action in the particular substantive provisions raised. This issue assumed locus standi under Article 7. The question is one of substance concerning the legal content of the provisions of the Mandate, especially Article 2.

A threshhold inquiry is whether the respondent's third preliminary objection in 1962 was one fairly termed jurisdictional by the 1966 Court, or whether its substantive emanations-that is to say, the extent to which it raised an issue necessarily involving and requiring an examination of the substantive provisions of the Mandate-constituted an adjudication of the admissibility of the claim. ${ }^{39}$

The Court in $1962 \mathrm{did}$ in fact consider the Mandate as a whole in determining the scope of the jurisdictional clause. The Court viewed Article 7 and the actions which could be brought pursuant thereto as "the final bulwark of protection by recourse to the Court

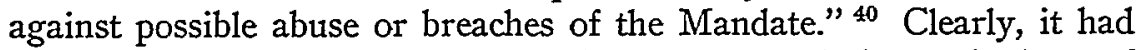
the full gamut of the Mandatory's obligations in mind, not the least of which were the obligations to the inhabitants contained in Article 2 "to promote the material and moral well-being and social progress of the inhabitants." Furthermore, in considering the respondent's third preliminary objection, the Court in 1962 determined that there was subject-matter jurisdiction, apparently assuming that the claims were admissible. Indeed, the language of the Court suggests that support for this assumption was found in Article 7 itself.

38 See 1 Rosenne, The Law and Practice of the International Court 327-28 (1965) (conferment of jurisdiction ratione materiae) [hereinafter cited as RosENNE].

39 There seems to be no reason why the Court could not have decided the question of admissibility in the preliminary phase of the case, proprio motu or otherwise. Had the issue been formally raised, however, the question could have been joined to the merits. Barcelona Traction, Light and Power Company, Itd. Case, [1964] I.C.J. 6. Nevertheless, it does not appear that even the majority of the Court in 1966 would have found, had the Court expressly decided the question of admissibility in the preliminary phase, that such determination would not be binding when the case reached the merits.

${ }^{40}$ South West Africa Cases, [1962] I.C.J. 336 (preliminary objections). 
The Respondent's contention runs counter to the natural and ordinary meaning of the provisions of Article 7 of the Mandate, which mentions "any dispute whatever" arising between the Mandatory and another Member of the League of Nations "relating to the interpretation or the application of the provisions of the Mandate." The language used is broad, clear and precise: it gives rise to no ambiguity and it permits of no exception. It refers to any dispute whatever relating not only to any one particular provision or provisions, but to "the provisions" of the Mandate, obviously meaning all or any provisions, whether they relate to substantive obligations of the Mandatory toward the inhabitants of the Territory or toward the other Members of the League or to its obligation to submit to supervision by the League under Article 6 or to protection under Article 7 itself. For the manifest scope and purport of the provisions of this Article indicate that the Members of the League were understood to have a legal right or interest in the observance by the Mandatory of its obligations both toward the inhabitants of the mandated Territory, and toward the League of Nations and its Members. ${ }^{41}$

\section{The Doctrine of Res Judicata}

An important question here is the effect that should be given to the language quoted above concerning the question of subject-matter jurisdiction and the meaning of the word "dispute" in Article 7. If the Court's reasoning in 1962 on the nature of the Mandatory's legal duties was not necessary to the question before it-the nature of Article 7-then the language above is dictum and its only relevance is as authority. ${ }^{42}$

Judge Koretsky argued in dissent that if the Court's conclusions as to the other provisions were necessary to the 1962 judgment on Article 7, they would be binding on the Court in 1966. Under

$41 \mathrm{Id}$. at 343. (Emphasis added.) Compare the language of the joint dissent of Judges Spender and Fitzmaurice.

To sum up, our study of the record confirms the view which we had antecedently and independently formed, on the basis of the language of Article 7 , and in the context of the Mandate as a whole. This view is, first, that Article 7 must be understood as referring to a dispute in the traditional sense of the term, as it would have been understood in 1920, namely a dispute between the actual parties before the Court about their own interests, in which they appear as representing themselves and not some other entity or interest; and secondly, that Article 7 in the general context and scheme of the Mandate, was intended to enable the Members of the League to protect their own rights and those of their nationals, and not to enable them to intervene in matters affecting solely the conduct of the Mandate in relation to the peoples of the mandated territory.

Id. at 558-59.

42 See Restateatent, Judgments $\$ 71$ (1942). 
Koretsky's view, the preclusive effect of a judgment of the Court not only pro obligatione habetur but also pro veritate."3 "And it cannot be said that what today was for the Court a veritas, will tomorrow be a non-veritas." 44 The reasons necessary to the legal conclusions, the consideranda, are thus binding on the Court. ${ }^{45}$ Authority for this position on the scope of res judicata is found in Article 56 of the Statute of the Court, which requires that "the judgment shall state the reasons on which it is based." ${ }^{48}$ The application of this rule in the South West Africa cases requires a determination of whether the assumption that there was a legal right in the applicants in the enforcement of the "conduct" provisions was necessary to the Court's finding in 1962 that there was a dispute within the meaning of Article 7, or whether, on the contrary, this assumption went beyond the operative part of the judgment. Koretsky asserted:

The reason of the 1962 Judgment relating to "a legal right or interest" of the Applicants served as a ground for the Court's decision to dismiss the third preliminary objection submitted by the Respondent. And what was then decided with the reasons "on which it is based" is finally not provisionally decided. And I repeat that these reasons cannot be reversed in the way chosen by the Court. ${ }^{4 \pi}$

The language of the 1962 Court, however, might suggest that the conclusion that the Applicants had a legal right or interest in the obligations owed the inhabitants and the League by the Mandatory

43 Thus, the 1962 judgment is binding not only as to the finding of jurisdiction to adjudicate on the merits, but also as to the reasons why there was such jurisdiction in the Court. South West Africa Cases, [1966] I.C.J. 240 (second phase).

44 Ibid.

$45 I d$. at 241. Support for Judge Koretsky's interpretation of res judicata is found in the dissenting opinion of Judge Anzilotti in the Chorzow Factory (interpretation) Case, P.C.I.J., ser. A, No. 13 (1927). In considering the principles of res judicata in Article 59 and 60 of the Statute of the Court, Judge Anzilotti stated:

[W]e have here the three traditional elements of identification, persona, petitum, causa petendi, for it is clear that "that particular case" (le cas qui a été décidé) covers both the object and the grounds of the claim.

$I d$. at 23. Rosenne calls this case "the classic enunciation of the law" and notes that res judicata has always been applied by the Court by reference to the Statute of the Court, and not as a general principle of law under Article 38. 1 RosENNE 624. Compare Da Costa en Schaake N.V. v. Netherlands Fiscal Administration (Cour de Justice de la Communité européene) 2 CCH Comar. MKr. Rep. $\Uparrow$ 8010, at 7240-45 (March 27, 1963) (conclusions of Advocate General Lagrange).

Judge Koretsky asserted:

The Judgment has not only a binding force between the parties (Article

59 of the Statute), it is final (Article 60 of the Statute). Being final, it is $\rightarrow$ one may say-final for the Court itself unless revised by the Court under the conditions and in accordance with the procedure prescribed in Article 61 of the Statute and Article 78 of the Rules of the Court.

South West Africa Cases, [1966] I.C.J. 240 (second phase). Article 61 of the Statute of the Court provides for revision within a certain time period only after the finding of new facts. 1 ROSENNE 429.

46 South West Africa Cases, [1966] I.C.J. 241 (second phase).

47 Ibid. 
under the sacred trust was derived, not from an evaluation of the provisions creating such substantive rights, but from the "provisions of this Article"-meaning Article 7.8 If this be true, it is not wholly correct to say that a finding of such a legal right or interest was necessary to the finding of subject-matter jurisdiction in the body of Article 7. In 1962, the Court viewed the substantive rights of the Mandate as coextensive with the subject-matter jurisdiction of Article 7.99 This fact would lend support to the view that the 1962 Court believed that in deciding the latter it was effectively deciding the former. In this sense, the Court's assumption of the admissibility of the claims was "necessary" to its disposition of the jurisdictional question. Thus, Judge Koretsky's view appears sound, and the assumption of admissibility should bind with a force equal to that of the 1962 judgment itself.

The procedure used by the Court in preserving for de novo consideration the question of the admissibility of the claims was curious. The Court relied on Article 62(3) of the Rules of the Court, which provides that "Upon receipt by the Registrar of a preliminary objection filed by a party, the proceedings on the merits shall be suspended . . . " Thus, the only thing decided in 1962, it seems, is that the Court had jurisdiction to adjudicate upon the merits of the claims. It is not clear what the Court would have done with Article 62 (3) had it decided expressly in 1962 that the claims were admissible, even though the issue was not raised explicitly in the preliminary objections. What is clear is that the Court believed that Article 62(3) gave it license to disregard the substance of the judgment on the preliminary objections. ${ }^{50}$

The Court's view of the non-preclusiveness of a judgment on preliminary objections, even putting aside objections to its legal foundation, runs counter to the policies of having a rule of res judicata. ${ }^{51}$ Nice questions of jurisprudence are presented. To what extent should

48 South West Africa Cases, [1962] I.C.J. 343 (preliminary objections).

49 See text accompanying note 41 silpra.

50 Judge Jessup dismissed this interpretation of Article 62(3). He noted that the rule was intended to have a limited procedural purpose regarding time limits for the proceedings on the merits and the obligations of parties to file written memorials; the rule was not intended to derogate from principles of res judicata. South West Africa Cases, [1966] I.C.J. 334 (second phase).

51 The doctrine of res judicata precludes the parties from showing what is or may be the truth. Why should not the truth prevail? The answer is based upon public policy. The interests of the state and of the parties require the putting of an end to controversies. One way of ending controversies is to preclude the bringing of an action after a period of time has elapsed, and thus a perfectly valid claim may be barred by a statute of limitations or by laches. The policy against relitigation is even stronger. If the validity or invalidity of a claim is established by a valid and final judgment, that claim cannot again be litigated. If an issue is actually litigated and determined, that issue cannot again be litigated between the parties even though it arises in an action based upon a different claim.

Scott, Collateral Estoppel by Judgment, 56 HARv. L. REV. 1 (1942). See also Note, Law of the Case, 40 Colun. L. Rev. 268 (1940). 
any court in a subsequent proceeding vary from a correct result, in the interest of following an incorrect judgment in deference to policies of fairness and predictability? Is the answer to this question in any way affected by the circumstances here, where changes in membership of the panel resulted in the overturning of a bare majority by an equally bare majority, and where the question presented in the latter phase of the case is one intimately connected with, although seemingly separate and distinct from, the decision already handed down? ${ }^{52}$

Probably one reason why the Court eschewed a strict rule of res judicata was its sensitivity to the sovereignty of States. For, while it might be appropriate for a municipal court to bind itself to an erroneous decision in the interest of fairness and predictability, such a result is perhaps unseemly where independent States have consented to be bound by a decision of an international tribunal..$^{53}$ It should be noted that redress in the courts is a departure from the normal manner in which States conduct their affairs.

\section{The Preclusiveness of the 1962 Judgment as a Matter of Treaty Interpretation}

It seems, then, that what the Court did in 1966 was merely to insulate itself from the argument that it had already found that the claims were admissible. It did this by praying in aid two rules: first, that jurisdictional clauses are adjectival (procedural), not substantive in nature; ${ }^{54}$ second, that under Article 62 (3) "a decision on a preliminary objection can never be preclusive of a matter appertaining to the merits, whether or not it has in fact been dealt with in connection with the preliminary objection." 55

Thus, the Court avoided the natural and ordinary meaning of the broadly worded jurisdictional clause. It apparently assumed that the intention of the parties to the Mandate, manifested in Article 7, shed no light upon the parties' intent with regard to the legal content of the other provisions of the Mandate. ${ }^{56}$ The Court's view of the matter, then, comes down to this: even though the scope of the jurisdictional

52 These problems are exacerbated by the nature of the Court: the number of judges, the length of tenure, the undue length of the proceedings and the fact that the Court is one of first instance as well as last resort. The South West Africa cases began November 4, 1960, and terminated July 18, 1966.

On the personnel of the Court, see generally, 1 RosenNe 165-220. For an interesting discussion of the composition of the Court and the disqualification of Judge Zafrullah Kahn from the South West African Cases, see Reisman, Revision of the South West Africa Cases, 7 VA. J. INT'L L. 1, 42-59 (1966).

53 See Da Costa en Schaake N.V. v. Netherlands Fiscal Administration (Cour de Justice de la Communité européene), 2 CCH Comr. MKT. REp. $\int 8010$, at 7240-45 (March 27, 1963) (conclusions of Advocate General Lagrange).

54 South West Africa Cases, [1966] I.C.J. 39 (second phase).

55 Id. at 37. Cf. Restatement, Judgments $\$ 49$ (1942).

56 The Court in 1962 took the contrary view. See South West Africa Cases, [1962] I.C.J. 343 (preliminary objections). See text accompanying notes 40-41, supra. 
clause is sufficiently broad to cover the kind of claim presented-one based on the non-material interests of the applicants-an analysis of the Mandate reveals that the parties thereto never intended that the Members of the League should have a legal right in the obligations of the Mandatory to the inhabitants and to the League.

It is submitted, however, that if the 1962 judgment stands as authoritative interpretation of Article 7, the holding of the Court in 1966 is erroneous. There is no reason to believe that parties who wrote a jurisdictional clause to permit the Court, acting under the Mandate, to hear cases involving the non-material interests of applicant States, would have written an instrument in which the non-material interests give rise only to inadmissible claims, that is, claims for which the Court is powerless to grant relief.

The provisions of the Mandate-jurisdictional and substantiveestablished obligations which were entered into simultaneously. The only purpose of the jurisdictional clause was to afford an opportunity for vindicating rights created in the Mandate. There was no reason for drafting a jurisdictional clause broader than the legal rights and duties created in the main body of the instrument. Whatever may be the value of the distinction between subject-matter jurisdiction and admissibility of claims in other areas of the law, such distinction is not sound in regard to the Mandate. To quote language used by the Court in another context, but serviceable here, "those who intended the one system cannot simultaneously have intended the other "57 Assuming that the 1962 judgment was an authoritative reading of Article 7-and it does not appear that the Court argued to the contrary-the 1966 judgment is erroneous as a matter of logical interpretation of international conventions. Manifestly, the Court's position runs afoul of the rule of effectiveness, ut res magis valeat quam pereat. ${ }^{58}$

\section{The Nature of the Applicants' Claims and the Legal Content of Article 2 of the Mandate}

One of the factors motivating the Court's decision may have been the apparent difficulty of finding a sufficient legal standard in Article 2 and a reluctance to expose the Mandatory to litigation without such a standard. The duty stated in Article 2 is broad: "to promote to the utmost the material and moral well-being and the social progress of the inhabitants of the territory." This duty, read

57 South West Africa Cases, [1966] I.C.J. 31 (second phase).

58 That the thing may have effect rather than be destroyed. Lauterpacht writes that the rule of effectiveness "constitutes the main feature" of the opinion of the Court in its opinion on International Status of South West Africa, [1950] I.C.J. 128 (advisory opinion). LAUTERPACHT, THE DEVELOPAENT OF INTERNATIONAL LAW BY THE INTERnational CoURT 280 (1958). There, the Court's decision ensured the continuation of the obligations created under the Mandate in spite of the fact that the organ which had created and supervised the Mandate no longer existed. 
together with the first clause of Article 2-"The Mandatory shall have full power of administration and legislation over the territory subject to the present Mandate as an integral portion of the Union of South Africa"-suggests that the discretionary power vested in the Mandatory was broad as well. Not surprisingly, the Respondent argued that the only actionable conduct under the Mandate would be conduct in bad faith. ${ }^{59}$

The way the various judges characterized the claims of the applicants seems to have determined, to some extent, how they evaluated the legal content of Article 2. It is noteworthy, moreover, that throughout the litigation of the case on the merits there was disagreement as to the nature of the applicants' claims. ${ }^{60}$ The majority framed the question of admissibility thus:

$[W]$ hether . . . any legal right or interest . . . was vested in the members of the League of Nations, including the present Applicants, individually and each in its own separate right to call for the carrying out of the mandates as regards their "conduct" clauses. . . .

"To call for the carrying out of the mandates" is a phrase which connotes important legal consequences if the general power to carry out

59 South West Africa Cases, [1966] I.C.J. 302.

60 This conflict between counsel for the applicants and the respondent resulted in a dispute over the admission of testimony over the objections of the applicants. Counsel for the applicants argued that the respondent's erroneous statement of the applicants' contentions "formed an improper basis for the testimony of the witnesses." Id. at 430 . The position of the applicants was stated thus:

There are two major branches of the Applicants' case. One relates to standards of interpretation which have been applied by competent international organizations as part of the scheme of the Mandate. This involves the standard of interpretation, of a content described by the Applicants, in relation to the supervisory organ responsible for the supervision of the Mandate, and also involves the relationship between that administrative agency and the Court. This branch of the case, therefore, reflects and is based upon a legal theory, which involves the mandate jurisprudence, which involves the clear, explicit and virtually unanimous pronouncements and judgments of the competent international organ which the Applicants submit, for reasons which have been set forth in detail, should be accepted by the Court as authoritative interpretations of the Mandate. It is apartheid we are talking about. If this witness or any other witness addresses himself as an expert or otherwise to the questions of discrimination and separation which are implicit in and reflected in the undisputed facts of record in this case, there would be no question of admissibility of such evidence so directed by competent witnesses with respect to that branch of the Applicants' case.

And, secondly, Mr. President, with respect to the norm, the rule of international law for which the Applicants contend in terms of Article 38 of the Statute-that, as the Court will well be aware, has been presented to the Court as an alternative and a cumulative, or supplemental, argument on the basis that the practice of States and the views of the competent international organs are so clear, so explicit, and so unanimous in respect of the policies against discrimination, that such standards have achieved the status of an international rule of law, as a legal conclusion based upon the application of Article 38.

Id. at 431 .

61 Id. at 22 . 
the mandates is discretionary; it suggests an encroachment upon such discretionary power. It is far different from seeking a declaration on the validity of a particular course of action in the light of objective standards of interpretation found in the Mandate (Judge Jessup's characterization $) ;{ }^{62}$ it is far different, moreover, from a petition for an injunction against, or declaration of the illegality of, those actions of the Mandatory which violate international norms (Judge Tanaka's characterization).$^{63}$

Under the majority's view, the Court was being asked to interfere with the administration of the mandated Territory; it was being asked to decide moral, political and social questions; ultimately, it was being asked to evaluate the utility of one social order as opposed to another. It is arguable that it was for the Mandatory to decide upon the efficacy of various social systems. To institute a new social policy against the will of the Mandatory, perhaps, would have required a political or administrative judgment not within the competence of the Court; ${ }^{64}$ such a judgment, on the other hand, was clearly within the competence of the League Council which, before its dissolution, had dealt with such questions.

Judges Jessup and Tanaka, in their dissenting opinions, ${ }^{65}$ saw no attempt by the applicants to foist upon the respondent one social

$62 I d$. at 328.

63 See text accompanying notes 74-83 infra.

64 To say that an issue before the Court is not justiciable because it turns on a "political" question in a sense assumes the conclusion. A question is "political" when the parties engaged in the dispute have not assented to be bound by judicial power in regard thereto. The subjects of municipal law are generally amenable to judicial process; there is a defined notion of sovereignty. In the international sphere, however, there is no defined sovereign to which all nations are subject. To the extent that there is no expressed intent to be bound by the rule of law, all questions are political. The thrust of the legal theory of positivism suggests that international disputes are presumptively political. To state that the duty of Article 2 of the Mandate is political merely means that the Mandatory has not assumed a legal obligation, not, as might be suggested, that the obligations of Article 2 are in some way inherently political.

The function of the "political question" in American law, it should be noted, also involves questions of sovereignty, that is, the relationship between the competing branches of the federal government or between the federal government and the states. Such a technique for not deciding questions before the courts, applied in the international context, has a different effect-it militates against the development of the rule of law among equal subjects.

65 An interesting collateral issue raised in the South West Africa Cases is the permissible scope of separate and dissenting opinions. President Judge Spender contended that when the Court's opinion is limited to an issue short of the ultimate merits of the case, judges writing separate and dissenting opinions should be similarly limited. [1966] I.C.J. 51-57. Apparently this was an effort by the judge to restrain, in future decisions, opinions such as that of Judge Van Wyk, the ad hoc judge from South Africa, who wrote an extensive apology for the policy of apartheid, [1966] I.C.J. 67-215 (second phase), and those of the dissenting judges.

Judge Jessup spoke to the issue of the scope of opinions before a group of students of the Academy of International Law at the Hague, the Netherlands, on July 16, 1966. He noted that those who constituted the Court made the decision to adopt the common-law method of permitting concurring and dissenting opinions, rather than the civil law approach where the court speaks with one voice. The value of dissenting opinions, said the Judge- who referred to Lauterpacht on this subject, see ILAUTERPACHT, silpra note 58, at 66-70-was two-fold: first, it encouraged the parties 
system in preference to another because of moral, social or political reasons per se. They argued that the Mandatory's conduct could be judged according to appropriate legal standards. Judge Jessup found a sufficient objective standard in the duty stated in Article 2 "to promote to the utmost the material and moral well-being and social progress of the inhabitants." 66 He asserted the existence of a contemporary standard of interpretation recognized by the international community according to which the Court might judge whether the Mandatory had fulfilled its obligations under Article 2. He relied for his principle of interpretation upon the resolutions of the United Nations General Assembly.

$[\mathrm{M}] \mathrm{y}$ conclusion does not rest upon the thesis that resolutions of the General Assembly have a general legislative character and by themselves create new rules of law. But the accumulation of expressions of condemnation of apartheid as reproduced in the pleadings of the Applicants in this case, especially as recorded in the resolutions of the General Assembly of the United Nations, are proof of the pertinent contemporary international community standard. ${ }^{67}$

He conceived of the applicants' claims as prayers for a declaratory judgment on the legality of apartheid in the light of this standard of interpretation. He stated: "The law abounds in examples of standards or criteria which are applied by courts as tests of human conduct." 68

to come before the court because of the knowledge that the position of the losing party might be vindicated by an exposition written by a dissenting judge; second, a wellreasoned dissenting opinion could itself contribute to the development of the law, by charting a course which the court might take in the future. Judge Jessup referred, as an illustration (and indirectly and perhaps unwittingly an indication of what was to come two days later) of this characteristic of the common-law method, to two recent decisions of the United States Supreme Court, NAACP v. Overstreet, 384 U.S. 118 (1966) (Mem.); Hicks v. District of Columbia, 383 U.S. 252 (1966) (Mem.), in which, although the decision of the Court was to dismiss certiorari as improvidently granted, fully-reasoned dissenting opinions were written on the merits. The 1966 judgment of the International Court resembles a dismissal of certiorari as improvidently granted in that it suggests a "now-you-see-it, now-you-don't" refusal to hear a case on the merits.

${ }^{66} I d$. at 433.

67 Id. at 441. See generally Asamoah, The Legal Effect of Resolutions of the General Assembly, 3 Colvar. J. of Transnat'i L. 210 (1965). Judge Jessup rebutted the view that the Mandatory could not be exposed to standards of international law, albeit standards of interpretation, that did not exist at the time that the Mandate was entered into. He noted that the purpise of the "sacred trust of civilization" stated in Article 22 of the Covenant was to help the inhabitants of the mandated territories to "stand by themselves under the strenuous conditions of the modern world." The Court's view that the obligations under the Mandate must be interpreted as they were understood in 1920 is not gainsaid by arguing that the term "modern world" was intended to be a dynamic concept, changing according to the social needs of the day. Thus, the parties should not be presumed to have intended in 1966, when the Mandate was still in effect, that the duty of the Mandatory stopped at bringing the inhabitants into the world of 1920 . Consequently, contemporary international standards of interpretation-even, arguably, international norms-might be invoked in order to define the Mandatory's duties under the Mandate. Id. at 439-40.

68 South West Africa Cases, [1966] I.C.J. 434 (second phase). 
Judge Jessup noted that the standard of interpretation was but one half of the applicant's case. The other was an alleged norm of international law proscribing racial discrimination, which is evidenced in and created by the practice of States and the pronouncements of competent international organs. ${ }^{69}$ Although Judge Jessup took issue with this latter part of the applicants' case, ${ }^{70}$ Judge Tanaka took up the argument of the applicants for a norm of international law, binding upon the Mandatory, which establishes the illegality of racial discrimination.

Judge Tanaka's dissenting opinion merits detailed consideration because it offers a sharply contrasting and well-reasoned alternative to the Court's interpretation of the obligations created by the instrument of mandate. He first considered the difficulty of evaluating the substance of the Mandatory's obligations without sufficient legal standards, suggesting that perhaps the creators and draftsmen of Article 22 and the Mandate did not fully consider the problems inherent in the obligations stated in Article 2, paragraph 2 of the Mandate:

[W] are inclined to conclude that the concept of the promotion of "material and moral well-being and social progress of the inhabitants" which constitutes the objectives of the Mandate for South West Africa (Article 2, paragraph 2), is in itself of political character and cannot be recognized as susceptible of judicial determination and execution. ${ }^{71}$

But this fact, according to the judge, does not mean that Article 2, paragraph 2 does not constitute a legal norm. He then described the process whereby a cultural or political norm is vested with "juridical value" - the process of "naturalization." 72 Such is the case, he asserted, with regard to the obligation of Article 2 .

Judge Tanaka admitted that it is fundamentally correct to say that in the area of discretionary power, an issue is justiciable only if the Mandatory acts in bad faith. ${ }^{73}$ He then turned, however, to the applicants' amendment of their Submission No. 4 with the insertion of the phrase "in the light of applicable international standards or international legal norm." Thereby, he said:

$69 \mathrm{Id}$. at 432 .

$70 I d$. at $432-33$.

71 Id. at 281.

Briefly, to promote the well-being and the progress of the inhabitants, many policies and measures are conceivable. The Mandatory has a discretionary power to choose those it considers to be the most appropriate and efficient means of realizing the said objectives of the Mandate.

Id. at 282 .

72 Id. at 281.

$73 I d$. at 283. 
Applicants' cause is no longer based directly on a violation of the well-being and progress by the practice of apartheid, but on the alleged violation of certain international standards or international legal norm and not directly on the obligation to promote the well-being and social progress of the inhabitants. There is no doubt that, if such standards and norm exist, their observance in itself may constitute part of Respondent's general obligations to promote the well-being and social progress. ${ }^{74}$

Thus, the alleged norm or standards pleaded in applicants' submissions constitute a limitation on the Mandatory's discretionary power under Article 2.

What then is the source of the international norm or standards which are incorporated in the Mandatory's general obligations as a limit upon its discretionary power? Judge Tanaka found such a norm in three sources of international law contained in Article 38 of the Statute of the Court. First, the norm of non-discrimination binds the respondent as part of the Charter of the United Nations; this is a norm of conventional international law under Article 38(1) (a) of the Statute of the Court. ${ }^{75}$ Second, Judge Tanaka found such a norm as part of customary international law under Article 38(1) (b), relying on the repetition of resolutions and declarations of international organs. ${ }^{76}$

Finally, Judge Tanaka found the norm of non-discrimination among "the general principles of law recognized by civilized nations" under Article 38(1) (c) of the Statute of the Court. Such "general principles" include not only basic principles of law, but also general theories of law, fundamental legal concepts, as well as "juridical truth." 77 In

$74 I d$, at 286.

75 The Charter, being of the nature of special international law, or the law of the organized international community, must be applied to all matters which come within the purposes and competence of the United Nations and with which member States are concerned, including the matter of the Mandate. Logic requires that, so long as we recognize the unity of personality, the same principle must govern both the conduct of a member State in the United Nations itself and also its conduct as a mandatory, particularly in the matter of the protection and guarantee of human rights and freedoms.

Id. at 290 .

76 This collective, cumulative and organic process of custom-generation can be characterized as the middle way between legislation by convention and the traditional process of custom making, and can be seen to have an important role from the viewpoint of the development of international law.

Id. at 292. This norm of customary international law, moreover, binds the Mandatory both in its capacity as a member of the United Nations and by way of interpretation of Article 2 of the Mandate. Id. at 293.

Judge Tanaka viewed this generation of custom as:

... nothing other than a simple clarification of what was not so clear 40 years ago. What ought to have been clear 40 years ago has been revealed by the creation of a new customary law which plays the role of authentic interpretation the effect of which is retroactive.

Id. at 294 .

77 Id. at 295. 
this context he distinguished general principles which are "private law principles found by the comparative law method and applicable by way of analogy to matters of an international character." 78 Such principles, common to all nations, are "of the character of jus gentum." 79 In addition, Judge Tanaka argued that Article 38(1) (c) embodies principles of the character of jus naturale. ${ }^{s 0}$ In regard to those general principles of law applicable to the international situation by way of analogy, he considered well-founded respondent's contention that

the alleged norm of non-differentiation as between individuals within a State on the basis of membership of a race, class or group could not be transferred by way of analogy to the international relationship, otherwise it would mean that all nations are to be treated equally despite the difference of race, colour, etc.-a conclusion which is absurd. ${ }^{81}$

The natural law principle of non-discrimination, however, neither depends on analogy nor on the consent of the nations subject to it. ${ }^{22}$ Evidence of the recognition of such a general principle is found in the constitutions of most of the civilized nations as well as in the declarations of the organs of the League of Nations, the United Nations, and other international bodies.

Judge Tanaka then stated the claims of the applicants in regard to the alleged norm:

What the Applicants seek to establish seems to be that the Respondent's practice of apartheid constitutes a violation of international standards and/or an international legal norm, namely the principle of equality and, as a result, a violation of the obligations to promote to the utmost, etc. If the violation of this principle exists, this will be necessarily followed by failure to promote the well-being, etc. The question is whether the principle of equality is applicable to the relationships of the mandate or not. ${ }^{83}$

7s Id. at $295-96$.

79 Id. at 296.

80 Ibid.

81 Id. at 296.

82 Judge Tanaka stated that Article $38(1)$ (c) of the Statute of the Court constitutes a compromise between the naturalists and the positivists, thus allowing for the application of natural law among the "general principles." Id. at 299. He also cited 2 Rosenne 610:

Having independent existence, their validity as legal norms does not derive from the consent of the parties as such. . . The Statute places this element on a footing of formal equality with two positivist elements of custom and treaty, and thus is positivist recognitions [sic] of the Grotian concept of the coexistence implying no subjugation of positive law and so-called natural law of nations in the Grotian sense.

83 South West Africa Cases, [1966] I.C.J. 301 (second phase). 
He answered this question summarily:

We consider that the principle of equality, although it is not expressly mentioned in the mandate instrument constitutes, by its nature, an integral part of the mandates system and therefore is embodied in the Mandate. From the natural-law character of this principle its inclusion in the Mandate must be justified. ${ }^{84}$

Having concluded that the principle of equality or non-discrimination is applicable to the obligations included in Article 22 of the Covenant and Article 2 of the Mandate, Judge Tanaka considered the substance of this principle in the context of its alleged violation by the respondent:

The divergence of views between the parties is summarized in the following formula: whether or not the policy of racial discrimination or separate development is per se incompatible with the well-being and social progress of the inhabitants, or in other terms, whether the policy of apartheid is illegal and constitutes a breach of the Mandate, or depends upon the motive (bona fides or mala fides), the result or effect. From the Respondent's standpoint apartheid is not per se prohibited but only a special kind of discrimination which leads to oppression is prohibited. ${ }^{85}$

Consequently, the applicant's position was that evidence of the effect or the practice of apartheid and the conditions within the mandated territory was not relevant to their submissions, whereas the respondent introduced testimony in support of the defense of the lack of bad faith and the allegation that apartheid had not led to oppression. ${ }^{86}$ In addition, the respondent urged the necessity of different treatment for diverse population groups for the purpose of promoting the wellbeing and social progress of the inhabitants of the territory. ${ }^{87}$

For the content of his natural law principle of equality, Judge Tanaka turned to the Aristotelian concepts of justitia commutativa and justitia distributiva and concluded: "The principle is that what is equal is to be treated equally and what is different is to be treated differently, namely, proportionately to the factual difference." 88 Fur-

S4 Ibid.

85 Id. at 302.

86 See note 60 supra.

87 South West Africa Cases, [1966] I.C.J. 307 (second phase).

$88 I d$. at 305 .

The most fundamental point in the equality principle is that all human beings as persons have an equal value in themselves, that they are the aim itself and not means for others, and that, therefore, slavery is denied. The idea of equality of men as persons and equal treatment as such is of a metaphysical nature. It underlies all modern, democratic and humanitarian law Ibid. systems as a principle of natural law. 
thermore, different treatment is permitted "only when it can be justified by the criterion of justice," or by the concept of reasonableness as developed by Anglo-Saxon law. ${ }^{89}$

Judge Tanaka thus concluded that discrimination on the basis of race renders the policy of apartheid violative of the principle of equality because it does not take into account concrete individual circumstances. Apartheid constitutes a violation of Article 2, paragraph 2 of the Mandate because "the observance of the principle of equality before the law must be considered as a necessary condition of the promotion of the material and moral well-being and the social progress of the inhabitants of the territory." ${ }^{90}$

\section{CONCLUSION}

The difference between the majority of the Court and the dissenting judges is essentially a clash between two theories of interpretation. The Court employs a contractual approach; that is, it interprets the obligations under the mandate instrument restrictively. ${ }^{91}$ The Court is loathe to subject the Mandatory to obligations which it did not assume expressly and unequivocally. At every turn, the goal is to limit the duties placed upon the Mandatory. Indeed, the Court's handling of the issue of the preclusive effect of the 1962 judgment on the preliminary objections evinces the spirit of voluntarism. The Court sacrifices the ideals of the Mandates System to the principles of State sovereignty in a context where such sovereignty was to be the servant of humanitarian ideals.

$89 \mathrm{Id}$. at 306 . In separating the reasonable discrimination from the unreasonable, Judge Tanaka considered the different treatment under the Minorities treaties by which the respondent sought to justify its own policy of different treatment. Under the the respondent sought to justiferent treatment was a means to cultural survival without the deprivation of rights and privileges enjoyed by the majority, and therefore the spirit of these treaties was "not negative and prohibitive, but positive and permissive." $I d$, at 307 . The examples of reasonable different treatment, e.g., the Minorities treaties, proved to Judge Tanaka that the applicants' contention that apartheid is per se violative of the international norm of equality was not supportable, to the extent that it would not permit an exception to the norm.

Equality being a principle and different treatment an exception, those who refer to the different treatment must prove its raison d'etre and its reasonableness.

The Applicants' norm of non-discrimination or non-separation, being conceived as of a per se nature, would appear not to permit any exception. The policy of apartheid or separate development which allots status, rights, duties, privileges or burdens on the basis of membership in a group, class or race rather than on the basis of individual merit, capacity or potential is illegal whether the motive be bona fide or mala fide, oppressive or benevolent; whether its effect or result be good or bad for the inhabitants.

Id. at 309 .

90 Id. at 314 .

91 Lauterpacht notes that the rule of restrictive interpretation results from a desire to protect the sovereignty of States. Lauterpacht, Restrictive Interpretation and the Principle of Effectiveness in the Interpretation of Treaties, 26 BRIT. Y.B. INT'L L. 48, 57-58 (1949). Judge Tanaka claimed that the method of the majority constituted "strict juristic formalism." South West Africa Cases, [1966] I.C.J. 276 (second phase). 
The method of Judge Tanaka, on the other hand, may be termed functional or teleological. The teleological approach is in a sense the maxim ut res magis valeat quam pereat writ large. The purpose here is to give effect to the function that the Mandates System was to serve. Thus, he found in the Mandate an "existence independent of the original or ulterior intent of the parties." ${ }_{22}$ It is this intent, moreover, independent of the original intent of the parties, that gives the Mandate an institutional as well as a contractual nature. This institutional side of the Mandates System was recognized in the Advisory Opinion on the Status of South West Africa in 1950 and the 1962 judgment. Both decisions held that the Mandate survived the dissolution of the League, one of the parties to the international "contract." 93

The teleological method of interpretation considers the "spirit and objectives as well as social reality" of the Mandates System. ${ }^{94}$ There is a sense that the obligations assumed by the Mandatory should be enforced in order to fulfill the goals of the system-to provide for the welfare of the inhabitants of the Territory who are not themselves subjects of international law-even in the absence of a common intention of the parties on the subject of whether the members of the League were to have a substantive right in the performance of the "sacred trust." This smacks of a theory of "necessity," and is,

92 Ibid. The problem here is the lacuna of legislative intent regarding the admissibility of claims based on the "conduct" provisions. The goal of interpretation is to discern the common intention of the parties. Iauterpacht writes:

For the contingency must be envisaged that in many cases the common intention of the parties is an assumption rather than a reality for some such reasons as that the parties while using identical language did not intend the same thing; or that one party deliberately used language of ambiguity; or that both parties, being unable to reach agreement.

LAUTERPACET, supra note 58, at 229. I auterpacht had written earlier that where: there was no common intention of the parties to adopt a positive and clear-cut solution on the particular subject-it is the right and duty of international judicial and arbitral agencies to impart an effect to these clauses by reference to the purpose of the treaty as a whole and to other relevant considerations, including the finality of adjudication.

Lauterpacht, supra note 91 , at 78.

Judge Tanaka writes of the teleological method:

Such attitude of interpretation has been known as a method of "libre recherche scientifique" or "Freirecht", mainly in civil law countries for threequarters of a century as emancipating judges from the rigid interpretation of written laws and emphasizing the creative role in their judicial activities. There is no reason to believe that the same method should be denied in the field of international law except the opposing tendency of strong voluntarism derived from the concept of sovereignty and not being in conformity with the concept of law which attributes to law an objective and independent existence from the will and intention of those to whom law is addressed.

In short the difference of opinions on the questions before us is in the final instance attributed to the difference between two methods of interpretation: teleological or sociological and conceptional or formalistic.

South West Africa Cases, [1966] I.C.J. 278 (second phase).

Schwarzenberger warns that "the functional method is apt to degenerate into legislation in disguise." 1 SCHWARZENBERGER, INTERNATIONAI LAW AS APPLIED BY INTERNATIONAL COURTS AND TRIBUNALS 517 (3d ed. 1957).

93 See text accompanying notes 7-14 supra.

94 South West Africa Cases, [1966] I.C.J. 276 (second phase). 
not surprisingly, anathema to the majority of the Court. Of course, this is not to say that there is no support for the applicants under a more modest approach to treaty interpretation. The plain meaning rule as applied to Article 7 and a sensitivity to the purpose of the instrument might well lead to a conclusion that the parties to the Mandate conceived of a legal right in the members of the League in the "conduct" provisions. ${ }^{95}$

Such an inference, if it be that, in the absence of explicit language, would, in the eyes of strict legal positivists, suggest treaty revision and judicial legislation. There is, to be sure, a sensitive area, not unknown to common law judges, where adjudication and legislation commingle. In writing of the principle of effectiveness and the significance of the common intention of the parties, Sir Hersh Lauterpacht noted that: "It touches upon one of the most controversial and elusive problems of jurisprudence-the nature and the limits of the judicial function." ${ }^{26}$ Judge Tanaka spoke candidly to this very point:

Undoubtedly a court of law declares what is the law, but does not legislate. In reality, however, where the borderline can be drawn is a very delicate and difficult matter. Of course, judges declare the law, but they do not function automatically. We cannot deny the possibility of some degree of creative element in their judicial activities. What is not permitted to judges, is to establish law independently of an existing legal system, institution or norm. What is permitted to them is to declare what can be logically inferred from the raison-d'etre of a legal system, legal institution or norm. In the latter case the lacuna in the intent of legislation or parties can be filled. ${ }^{97}$

Part of the argument against finding a common intention of the parties to confer the kind of substantive rights here asserted was "the

95 There is reason to believe, as did the Court in 1962, that the broadly worded compromissory clause of Article 7 of the Mandate was itself a manifestation of the intention of the parties to confer upon the members of the League the kind of substantive rights urged by the applicants. Judge Wellington Koo adopted this view in his dissenting opinion in 1966:

The broad, plain and comprehensive language of the provision implies that

the content and scope of the legal right or interest of the Members of the

League of Nations is co-extensive with the obligations of the Mandatory under

the Mandate; it is not restricted to the content of the said Article 5.

If it were to be interpreted as so limited, such interpretation would obviously be incompatible with the all-embracing term "the provisions of the Mandate". If it had been intended by the authors of the instrument to be so restricted in meaning and content, it would have been a simple thing to mention "Article 5" instead of the actual term "the provisions of the Mandate" -as stated in the compromissory clause. There is a Chinese proverb put in the form of a question: Why write a long and big essay on such a small subject?

Id. at $219-20$.

96 Lauterpacht, supra note 91 , at 82.

97 South West Africa Cases, [1966] I.C.J. 277 (second phase). 
state of development of the concept and institution of compulsory jurisdiction in the period of the early twenties and the general reluctance to assume such an extensive and onerous obligation." ${ }^{28}$ But, on the contrary, the Mandates System, indeed the League itself, was a new kind of institution imbued with the hopes and idealism of a new era. Judge Wellington Koo, writing in dissent, pointed out that the Mandates System was not the only manifestation of a new order of legal rights and duties. The Constitution of the International Labor Organization and the minorities treaties conferred substantive rights in the absence of traditional material interests. ${ }^{99}$

The very language of the Mandate and of the Covenant conveys the idea that, at least in regard to the territories in which the inhabitants were unable to stand by themselves, the material interests of States should take a position subordinate to those of the indigenous population. This was a "sacred trust of civilization." The release by the Principal Allied and Associated Powers of their traditional rights of annexation in regard to these territories constituted a unique renunciation of material self-interest. One should not conclude, therefore, that it was the intention of the parties to the mandates to supplant the material interests of several States with the material interests of one State-the Mandatory-save as a means of insuring that the welfare of the inhabitants be secured.

The rights of the Mandatory in relation to the mandated territory and the inhabitants have their foundation in the obligations of the Mandatory and they are, so to speak, mere tools given to enable it to fulfill its obligations. The fact is that each Mandate under the Mandates System constitutes a new international institution, the primary, overriding purpose of which is to promote "the well-being and development" of the people of the territory under the Mandate. ${ }^{100}$

With this conception of the Mandate in mind, it is difficult to support a theory of interpretation that limits the duties of the Mandatory to the specific terms of the instrument, construed with the begrudging fastidiousness used to interpret an international contract, to the detriment of the inhabitants, for whose benefit the Mandate was created. The nature of the mandate instrument is not the same as that of the traditional kind of treaty, bilateral or multilateral, in which the only parties in interest are the high contracting partiessovereign States. The unique feature of the Mandates System was the effectuation of rights of third parties, not subjects of international law, incapable of independently vindicating their own rights. In this

$98 I d$. at 226.

99 Ibid.

100 South West Africa Cases, [1962] I.C.J. 329 (preliminary objections). 
respect, it is no answer that the administration of the mandates was to be overseen by the League Council, for it is undisputed that because of the unanimity rule, the Council could never have protected effectively the interests of the inhabitants of the mandated territories against the powers of an irresponsible mandatory. Therefore, to the extent that the goals of the Mandates System are defeated by a theory of interpretation giving primacy to the sovereignty of a State occupying the subject territory by the grace of that institution, the decision of the Court rests upon an inappropriate principle of law, since the interests of the Mandatory were intended to be subordinate to those of the inhabitants of the Territory. This fact was expressly noted by the Court in 1950:

The authority which the Union Government exercises over the Territory is based on the Mandate. If the Mandate lapsed, as the Union Government contends, the latter's authority would equally have lapsed. To retain the rights derived from the Mandate and to deny the obligations thereunder could not be justified. ${ }^{101}$

Ironically and erroneously, the decision of the Court in 1966 affirmed in the Union of South Africa all the rights granted pursuant to the Mandate while effectively denying the obligations owed the inhabitants of South West Africa. The Court has chosen a theory of interpretation and a set of norms and standards inappropriate for and insensitive to the purposes of the instrument before it. ${ }^{102}$

101 International Status of South West Africa, [1950] I.C.J. 133 (advisory opinion). (Emphasis added.)

102 On October 27, 1966 "The [United Nations] General Assembly proclaimed . . the termination of South Africa's mandate over South West Africa." N.Y. Times, Oct. 28,1966 , p. 1 , col. 4. 